\title{
人工内耳埋め込み手術奏効のムンプス壟症例
}

\author{
菊田＼cjkstart周・熊川 孝三・徳永 英吉*・山根 雅昭

\section{Two Cases of Effective Cochlear Implantations for Deafness Following Mumps}

\author{
Shu Kikuta, Kozo Kumakawa and Masaaki Yamane \\ (Toranomon Hospital) \\ Eikichi Tokunaga \\ (Ageo Central General Hospital)
}

\begin{abstract}
While it is well known that mumps is a potential cause of deafness, it is not generally appreciated that it can produce total deafness. The damage is usually unilateral but bilateral disorder has been recorded. Deafness following mumps is usually severe and generally permanent. Only a mumps vaccination prevents deafness. Two cases are presented with severe bilateral hearing loss following mumps in spite of intensive conventional therapies. A 5 year-old female without natural infections of mumps or mumps vaccination already had bilateral deafness on hospitalization. She had no vestibular symptoms. After 5 months, she had cochlear implantation therapy. A 26 year-old woman without natural infections of mumps or mumps vaccination had bilateral progressive deafness in 2 weeks and temporary vestibular symptoms. After 6 months, she also had cochlear implantation therapy. The hearing ability of both cases after operation was very satisfactory owing to no complications (otitis media or malformation), enough inserting channels and comprehensive rehabilitations. We emphasize the importance of mumps vaccination and recommend a cochlear implant therapy for bilateral total deafness following mumps.
\end{abstract}

Key words : cochlear implantation, deafness, mumps

\section{はじめに}

ムンプスウイルスは，パラミクソウイルス族に属する RNA ウイルスで, 耳下腺, 顎下腺, 舌下腺などの唾液腺 や膵臓, 精巣, 卵巣などの実質性臓器炎を引き起こす以 外に, 神経親和性が高く, 種々の中枢神経感染症を起こ す1)。また，血清型は 1 種類で，いったん罹患すればほ とんどの個体で，終生免疫が成立することが知られてい る.ムンプスによる内耳障害の発生は，ムンプス罹患患 者の $0.005 \%$ とされ2)，通常は一側性であるが，まれに両 側難聴を引き起こす3).われわれは人工内耳埋め込み手 術が奏効した両側ムンプス壟の 2 症例を経験した. ムン
プス罷に対する人工内耳埋め込み手術の効果を中心に疫 学的考察を加えて報告する.

症例 $1: 5$ 歳, 女児.

家族歴：特記すべきことなし。

既往歴：ムンプス自然感染，予防接種歷なし.

現病歴: 平成 12 年 7 月 9 日, 両側耳下腺腫脹が出現 し，7月 12 日夕刻に両側難聴を両親に訴えたため， 7 月 17日近医を受診した。受診時耳内所見に異常を認めず， 眼振む認めなかった。 純音聴力検查上, 右 $120 \mathrm{dBHL}$, 左 
$125 \mathrm{dBHL}$ の高度感音難聴を認めた. 難聴出現以前の聴力 や言語発達には異常を認めなかった。

血液検查所見：初診時採血で, ムンプス IgM（EIA） 15.83 （基準值 0.80 未満）と高值であった。 その他，血 液生化学検查上異常を認めなかった。

ABR 検査： 105 dBSPL にて両側とも無反応.

カロリック検査：施行せず.

耳 X 線：異常なし.

MRI, CT 検査: 中耳炎, 内耳奇形等, 異常所見は認めず.

経過 : ムンプス難聴確実例と診断されたため, 初診時 よりステロイド治療（リンデロン $4 \mathrm{mg}$ より漸減）を行 うも効果なく, 聴力不変でリハビリテーションを開始, 半年後の平成 13 年 1 月 18 日, 左人工内耳埋め込み手術 を施行した. コクレア社製 $\mathrm{N} 24$ を使用し, 電極 22 個, 支 持電極 1 個, 計 23 個が挿入された.

成績: 手術後経過に問題なく, 聴覚のみの聴取能は単 音節 86\%, 福田版単語リストで 70\% と良好な成績であっ た（表 1). 言語性 IQ119, 動作性 IQ157, 全 IQ141 と言 語, 動作の発達は良好であった. 現在, 普通学校に通学 している.

症例 $2: 29$ 歳, 女性.

家族歴: 平成 14 年 2 月末, 長女がムンプス罹患.

既往歴 : ムンプス自然感染, 予防接種歴なし.

現病歴: 3 月 11 日両側耳下腺腫脹が出現, 3 月 12 日左 耳閉感, 左耳鳴が出現, 3 月 13 日回転性めまいが出現し たため, 3 月 14 日に近医を受診したところ, 純音聴力検 查では右 $12.5 \mathrm{dBHL}$, 左 $58.8 \mathrm{dBHL}$ であった. 急性感音 難聴疑いでステロイド治療（詳細不明）を開始するも，3 月 18 日に右耳鳴, 難聴出現, 3 月 19 日より紹介先病院 でステロイド（ソルコーテフ $500 \mathrm{mg}$ より開始, 計 25 日 間投与), $\gamma$-グロブリン治療 (ベニロン $5 \mathrm{~g}, 6$ 日間), 高

表 1 両症例のまとめ

\begin{tabular}{|c|c|c|}
\hline & 症例 1 （5 歳女児） & 症例 2 (29 歳女性) \\
\hline 失聴までの期間 & 8 日 & 14 日 \\
\hline 前庭症状 & $(-)$ & 回転性めまい \\
\hline 失聴期間 & 約 6 力月 & 約 5 力月 \\
\hline 電極 & $\begin{array}{l}\text { コクレア社製 } N 24 \\
23 \text { 電極挿入 }\end{array}$ & $\begin{array}{l}\text { クラリオン } \mathrm{S} \\
16 \text { 電極挿入 }\end{array}$ \\
\hline 術後の言語聴取能 & $\begin{array}{l}\text { 単音節 86\% } \\
\text { 福田版単語リスト } \\
70 \%\end{array}$ & $\begin{array}{l}\mathrm{CI} 2002 \text { 年評価法 } \\
\text { 単語聴取能 } 100 \% \\
\text { 文節聴取能 } 93 \% \\
\text { 語文聴取能 } 73 \%\end{array}$ \\
\hline
\end{tabular}

圧酸素療法（2 気圧， 60 分）を行うも, 聴力低下はさら に進行し，3月 25 日に両側 $110 \mathrm{dBHL}$ となった（図 1).

血液検查所見：初診時採血で，ムンプス IgM（EIA） 13.68 (基準値 0.80 未満)，ムンプス IgG（EIA） 70.1 (基 準値 2.0 末満）と高値であった。

$\mathrm{ABR}$ 検查 : $90 \mathrm{dBSPL}$ にて両側とも無反応.

カロリックテスト : 空気 $10^{\circ} \mathrm{C}$ 刺激にて, 右 $32^{\circ} /$ 秒, 左 39॰/秒で, CP を認めなかった。

MRI, CT 検查: 中耳炎, 内耳奇形等, 異常所見は認めず. 経過：あらゆる治療に反応せず, 聴力は不変で, 約 5 カ 月後の平成 14 年 9 月 11 日に右人工内耳埋め込み手術を 施行した. クラリオン $\mathrm{S}$ を使用し, 16 電極が挿入された.

成績: CI 2002 年評価法による聴覚のみの単語聴取能は $100 \%$ ，文節聴取能は $93 \%$ ，語文聴取能は $73 \%$ であり， 良好な成績であった（表 1).

表 2 に昭和 62 年度改訂ムンプス難聴の診断基準, 表 3 にムンプス難聴の特徴を示す ${ }^{4)}$ 8). 急性感音難聴の原 因としてウイルス感染はよく知られ，特に血管条，ライ スネル膜, コルチ器内支持細胞に親和性のあるムンプス ウイルスが，高い頻度で障害を引き起こし，内耳迷路炎 を引き起こすことも知られている ${ }^{9)}$. その発生はムンプ 不感染の重症度, 合併症の有無とは相関がなく, 大多数 の患者で一側耳の高度急性感音難聴を引き起こすが，ま れに両側の高度難聴を引き起こす.

耳下腺腫脹から難聴発症までの期間は, 14 日以内に約 半数が現れるとされるが5), 難聴が耳下腺腫脹に先行し たり, 耳下腺腫脹を示さない場合, あるいはムンプス不 顕性感染に伴い難聴が発生する場合もあるので ${ }^{10)}$, 急性 感音難聴の患者を診た場合は注意が必要である.これら ムンプスウイルスによる難聴は，治療に反応する症例は 一部あるものの ${ }^{6)}$ ほとんどはいかなる治療手段をもっ てしても治療抵抗性で, 症例 2 のように難聴が起こる以 前にステロイド治療を始めたとしても，その発生をくい 止めることはできず部分的な改善すらほとんど期待でき ないのが現状である.

この難聴の成立過程は, 突発性難聴のようなある時突 然に気付く形式とは異なり，4〜5日の経過で徐々に進 行し, 高度急性感音難聴を残す。前庭症状については, 小児より成人の方が随伴する可能性が高くなる傾向にあ り7), 今回の症例でもその傾向が認められた. ただし, 難 
(dB)

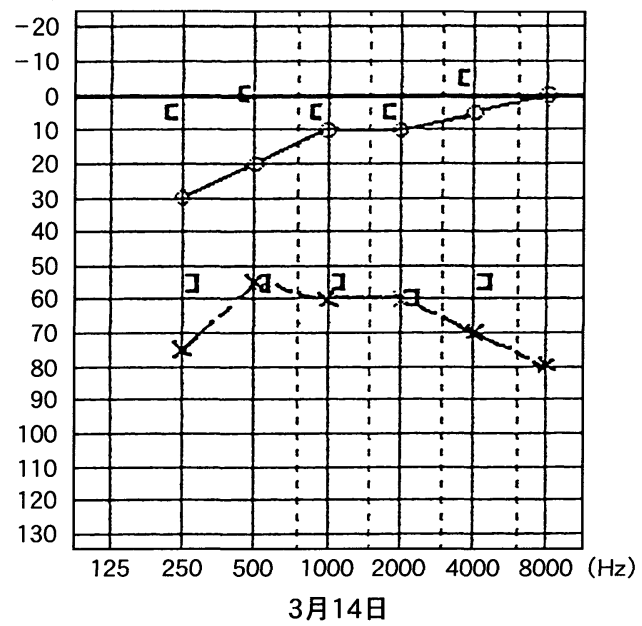

(dB)

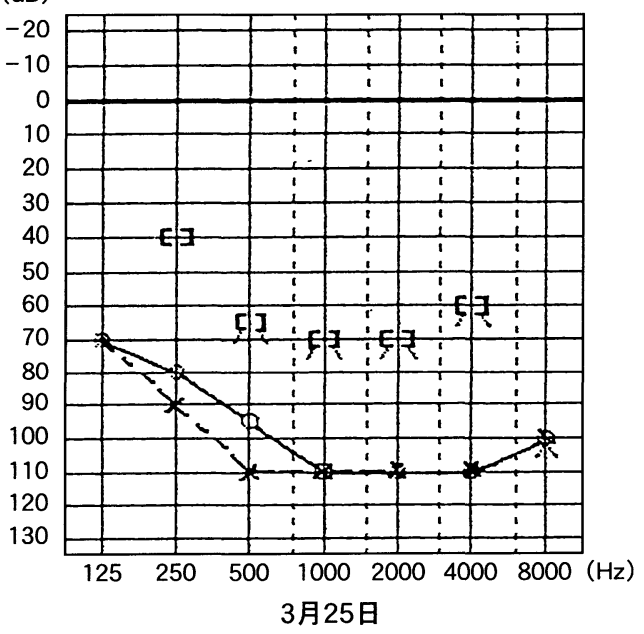

聴が高度で軽快しにくいのに対して, 前庭症状は一過性 で長くとも $1 \sim 2$ 月で治まるのが特徴である ${ }^{8}$. 前庭症 状が年齢により発現を異にするのかは疑問であり, 今後 の検討が必要である.

ムンプス難聴の発生率は，ムンプス罹患患者の 0.005 \%とされ ${ }^{2)}$, 両側ムンプス難聴の発生率については, さ らにその 10 分の 1 程度とされる11. ムンプス感染症は一 般的に軽症と考えられがちであるが，今回のような合併 症を考えると必ずしも軽症ではなく，ムンプスウイルス は一度の感染で終生免疫の獲得が可能なので, ワクチン によって予防することが望ましい. ワクチン接種による 難聴の発生の報告はあるものの ${ }^{12)}$, 自然感染による難聴 発生の方がはるかに高く, 昭和 $54 \sim 59$ 年のデータでム ンプスワクチンの接種率の増加に相まって, ムンプス難 聴患者の減少が報告されている ${ }^{13)}$.
(dB)

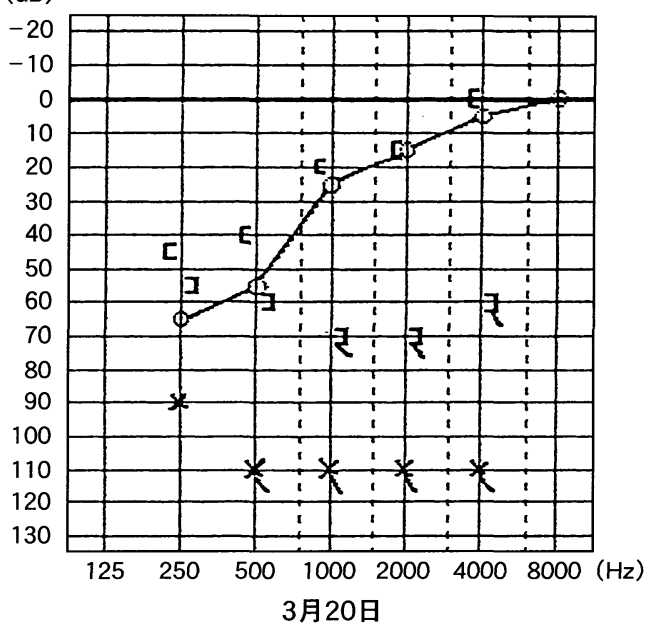

図 1 純音聴力検査の推移（症例 2)

3 月 14 日 (近医受診時)， 3 月 20 日， 3 月 25 日. 経過 とともに右聴力の低下も認めた. 3 月 25 日には, ほぼ 両側聾である.
以上より, 一度発症したら治療抵抗性で, 重篤な後遺 症を残すムンプス難聴の発症を予防するには, 現段階で はワクチン接種以外になく, その重要性を喚起したい. 特に片側性難聴がある人, あるいは女性の場合は子供か らの感染機会を考えるとワクチン接種は推奨されるべき である。

今回, 不幸にして両側壟に陥り, 人工内耳埋め込み手 術を選択したが, 本症例の手術後の聴取能はきわめて良 好であった. その理由として, 患者, 家族への十分な説 明の後, 早期にリハビリテーションを行い, 失聴期間の 短い間に手術を行ったことと, 中耳炎や奇形等の合併症 むなく, 手術操作も満足いくものであったことが挙げら れる. したがって，ムンプスが原因の両耳壟に対する人 工内耳埋め込み手術は有効な治療法で, その効果が示さ れたといえよう．症例 1 の女児は車の後部席から母の話 
表 2 ムンプス難聴診断基準（昭和 62 年度改訂） （厚生省特定疾患急性高度難聴調查研究班）

\section{1. 確実例}

1）耳下腺・顎下腺腫脹など臨床的に明らかなムンプス症 例で, 腫脹出現 4 日前より出現後 18 日以内に発症した 急性高度感音難聴の症例（この場合，必ずしも血清学 的検查は必要でない)

2）臨床的にはムンプスが明らかでない症例で，急性高度 感音難聴発症直後から $2 \sim 3$ 週間後にかけて血清ムン プス抗体価が有意の上昇を示した症例

注 1：1）においては, 初めの腫脹側からの日をいう

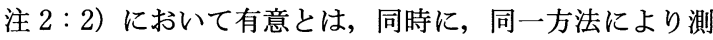
定して 4 倍以上になったものをいう

注 3 : 難聴の程度は必ずしも高度でない症例もある

\section{2. 準確実例}

急性高度難聴発症後 3 カ月以内にムンプス $\operatorname{IgM}$ 抗体が検出 された症例

\section{3. 参考例}

臨床的にムンプスによる難聴と考えられた症例 注 $1:$ 家族・友人にムンプス罹患があった症例など 注 2 ：確実例 1）における日数と差のあった症例

\section{表 3 ムンプス難聴の特徴 ${ }^{4)}$ ８)}

・ムンプス罹患患者の約 $0.005 \%$ に発生し, 一側性のことが多 いが，ムンプス難聴患者の約 10 分の 1 に両側で発生する

・腫脹出現 4 日前より,出現後 18 日以内に発生することが多い

・まれに治療に反応する症例むあるが，一般に高度感音難聴 もしくは襲となり，予後は非常に不良である

・前庭機能障害は約半数にみられ，年齢が高くなるほど発生 頻度は高くなる傾向にあるが, 難聴に比べて軽微で数か月 以内に回復する例が多い

・血清学的にムンプス抗体の測定が診断に有用である

すことがわかるほどである.

両側ムンプス壟は非常にまれではあるが，健常人の突 然の失聴という例外的な患者が発生する事実は，決して 看過できない重大な問題を含んでいる，ムンプス難聴の 詳細な病理学的検討の報告はいまだ十分とはいえず ${ }^{14)}$, 今後，症例の集積と検討が求められる.

\section{まとめ}

1. 人工内耳埋め込み手術を行った両側ムンプス壟の2 症例を報告した。

2. 現在のところ，ムンプス難聴を予防するには，ワク
チン予防接種が妥当である.

3. 不幸にして両側ムンプス聾に陥った場合は, 失聴期 間の短い間に人工内耳埋め込み手術治療が勧められる.

\section{参考文献}

1）西條政幸, 藤田晃三：ムンプスウイルス. 日本臨牃 $55: 870$ $\sim 875,1997$.

2) Everberg $G$ : Deafness following mumps. Acta Otolaryngol $48: 397 \sim 403,1957$.

3) Bitnun $S$, Rakover $Y$ and Rosen $G$ : Acute bilateral total deafness complicating mumps. J Laryngol Otol $100: 943 \sim 945$, 1986.

4) Hall R and Richards $H$ : Hearing loss due to mumps. Arch Dis Child $62: 189 \sim 191,1987$.

5）柳原尚明, 西岡出雄, 佐藤英光 : 愛媛県下におけるムンプ 又難聴の疫学調查第二報. 厚生省特定疾患「急性高度難聴」 調查研究班 昭和 58 年度研究業績報告書 : $47 \sim 50,1984$.

6）岡本牧人, 設楽哲也, 八尾和雄 : ムンプスによる感音難聴 一ろらでない症例について一. 日耳鼻 81:616〜 625, 1985.

7）村上嘉彦：ムンプス難聴. JOHNS 10：929〜 934, 1994.

8) Mizushima N and Murakami Y : Deafness following mumps; the possible pathogenesis and incidence of deafness. Auris Nasus Larynx 13 Suppl 1: S55 S57, 1986.

9) Davis LE and Johnson RT : Experimental viral infection of the inner ear. I. Acute infections of the newborn hamster labyrinth. Lab Invest $34: 349 \sim 356,1976$.

10) Fukuda S, Chida E, Kuroda T, et al. : An anti-mumps IgM antibody level in the serum idiopathic sudden sensorineural hearing loss. Auris Nasus Larynx 28 Suppl : S3 S5, 2001.

11）大島弘至，降矢宜成：流行性耳下腺炎性壟の臨床的観察. 日耳鼻 $59: 1351 \sim 1362,1956$.

12）古賀啓次郎：MMR 予防接種後に起こった両側急性高度難 聴の一症例. 日耳鼻 $94: 1142 \sim 1145,1991$.

13）神崎 仁，木村慶子：東京都内一小中学校におけるムンプ ス罹患率，ワクチン接種率と合併症に関する調査結果. 厚 生省特定疾患急性高度難聴調查研究班 昭和 59 年度研究報 告書. $41 \sim 42,1985$.

14）福田 諭, 石川和郎：ウイルス性難聴の病理. JOHNS 9 : $31 \sim 35,1993$

原稿受付：平成16年 2 月 16 日 原稿採択：平成16年 3 月 17 日 別刷請求先：菊田 周 干105-8470 東京都港区虎の門2-2-2 虎の門病院耳鼻咽喉科 